保健物理 Vol. 1 (1966)

低出力原子炉を利用した中性子線量校正

$$
\text { 西脇安* 志水秀 文** }
$$

\title{
A Neutron Dose Calibration by a Low Power Reactor
}

\author{
By Yasushi NISHIWAKI and Hidebumi SHIMIZU
}

\begin{abstract}
A few methods for neutron dose measurement have been examined. In this paper, a simple method for dose calibration by a low power reactor is introduced. Calibration with the theoretically calculated values of some neutron dosimeters was made. This calibration was based upon the neutron flux values estimated by the activation method using the neutron field of UTR-B operating at $0.1 \mathrm{~W}$. On The calibration with the Bendix fast neutron dosimeter and thermal neutron dosimeters, the experimental values were found to be close enough to the theoritical values to be of practical use from the operational health physics stand point.
\end{abstract}

\section{1. 緒言}

近大原子炉を利用した線量校正の利点は，炉内にたま っている核分裂生成物からの $\gamma$ 線が比較的よわく照射 Space が大きく,場所による中性子束もあまり変りなく， 中性子束が方向的に均一なことである。これにたいし 普通の原子炉では（a）日常高出力で運転しているため, 低出力運転を行って線量校正をしようとする場合たまっ ている核分裂生成物からの ではなく校正が正確に行われない。(b) 中性子束が方向 的に一様でない。（c）利用できる照射 Space が一般に 十分大きくない。(d) Subcritical assembly では測定器 自身の poison 効果, 遮蔽効果が問題となり, その補正 を正確に行うことはかなり問題になるが，目的に適した 原子炉があれば,その問題はずっと楽になる。Subcritical assembly ないし，Standard pileを利用した場合，これ らも熱中性子束に多少の方向性をもつのが 缺点になる が，本方法との優劣は微妙である。速中性子にたいして 熱中性子の場合よりその缺点は顕著になる。

今回は例として高速中性子用ポケット線量計及び熱中 性子用ポケット線量計について検討した結果を報告す る。
（1）高速中性子用ポケット線量計の線量校正法

$1 \mathrm{mrem}$ に相当する粒子束密度の時間積分量は第 1 表 の通りである。此の表は, 科学技術庁, S. John 氏, Los Alamos Laboratory 報告について計算した。

近大原子炉 (UTR-B 熱出力 $0.01 \mathrm{~W}$ ) で実験に使用 した中性子源挿入点における中性子の平均エネルギーは 約 $2 \mathrm{MeV}$ で速中性子束は約 $1 \times 10^{4} \mathrm{n} / \mathrm{cm}^{2} \bullet \mathrm{sec}$ である。 一方 中性子線量計の測定可能範囲は $0 \sim 200 \mathrm{mrad}$ であ る。従って $200 \times 8.8=1760 \mathrm{mrem}$ まで測定可能となる ので, 測定場所 (中性子源抑入場所) における線量校正 は熱出力 $0.01 \mathrm{~W}$ 運転で何分間で $200 \mathrm{mrad}$ になるかは 次式によって計算される。

1）科学技術庁報告の場合

$$
\frac{19,200\left(\mathrm{n} / \mathrm{cm}^{2}\right) \times 1760}{1 \times 10^{4}\left(\mathrm{n} / \mathrm{cm}^{2} \cdot \mathrm{sec}\right)} \fallingdotseq 3.4 \times 10^{3}(\mathrm{sec}) \cdots
$$

従って，(1)より UTR-B 熱出力 $0.01 \mathrm{~W}$ 運転で約57分

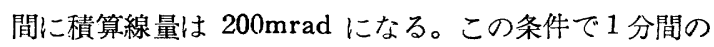
積算線量は約 $32 \mathrm{mrem}$ となる。このようにして求めら れた值を一般化すると, 時間 $\mathrm{t}(\mathrm{min})$ と線量 $\mathrm{D}(\mathrm{rem})$

* 東京工業大学原子炉工学研究所 (Research Laboratory of Nuclear Reactor, Chemical School, Ground Self Defense Force, Omiya, Japan)

** 陸上自衛隊化学学校研究課 (Tokyo Institute of Technology) 
との関係は

$$
\mathrm{D}=32.0 \mathrm{t} \cdots \cdot \cdot(2)
$$

となる。これを科学技術庁報告の理論值とする。

2）S. John 氏報告の場合

$1 \mathrm{mrem}$ に相当する粓子束密度の時間積分量は 1 週間 40 時間㗢く人の最大許享線量を $100 \mathrm{mrem}, 300 \mathrm{mrem}$ と した場合から算出された值の各々の平均値を採用すると

$$
\frac{27,593\left(\mathrm{n} / \mathrm{cm}^{2}\right) \times 1760}{1 \times 10^{4}\left(\mathrm{n} / \mathrm{cm}^{2} \cdot \mathrm{sec}\right)} \doteqdot 4.9 \times 10^{3}(\mathrm{sec}) \cdot
$$

從って(3)より UTR-B 熱出力 $0.01 \mathrm{~W}$ 運転で約80分

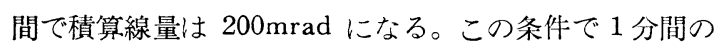

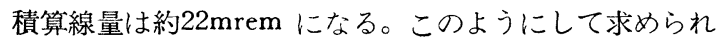
た值を一般化すると時間 $\mathrm{t}(\mathrm{min})$ と線量 $\mathrm{D}(\mathrm{rem})$ との 関係は

$$
\mathrm{D}=22 \mathrm{t} \cdots \cdots(4)
$$

となる。これを S. John 氏報告の理論值とする。

2. 熱中性子用ポケット線量計の線量較正法

熱中性子領域における $1 \mathrm{mrem} に$ 相当する粒子束密度 の時間積分量は第 1 表から明らかなように科学技術庁報 告と S. John 氏報告とはほとんど相違がないのでこれ を統一して $960,000 \mathrm{n} / \mathrm{cm}^{2}$ とした。実験に使用した中 性子雨入点における熱中性子束は約 $1 \times 10^{5} \mathrm{n} / \mathrm{cm}^{2} \cdot \mathrm{sec} て ゙$ ある。一方中性子線量計の測定可能範囲は $0 \sim 120 \mathrm{mrem}$ である。従って測定場所（中性子源㨂入場所）における 線量較正は熱出力 $0.01 \mathrm{~W}$ 運転で何分間で $120 \mathrm{mrem} に$ なるかは次式によって計算される。

$$
\frac{960,000 \times 120}{1 \times 10^{5}} \doteqdot 1.1 \times 10^{3}(\mathrm{sec}) \cdots \cdots(5)
$$

従って(5)より UTR-B 熱出力 $0.01 \mathrm{~W}$ 運転で約18分

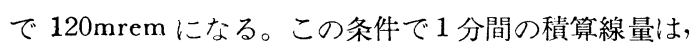
6. $6 \mathrm{mrem}$ になる。このようにして求められた值を一般 化すると時間 $\mathrm{t}(\mathrm{min})$ と線量 $\mathrm{D}(\mathrm{rem})$ との関係は

$$
\mathrm{D}=6.6 \mathrm{t} \cdots \cdots(6)
$$

となる。これを科学技術广 及び S. John 氏報告の理論 做とする。

\section{3. 実 験 方 法}

使用した高速中性子用ポケット線量尌は, Bendix 社 製 No. 0204 熱中性子用ポケット線量計は No. 60076, No. 60077 である。高速中性子用ボケット線量計は中性 子と $\gamma$ 線量の和が測定されるものなので, 同時に 測定は理研製 No. 7963，No. 12487 を使用した。高速中 性子用ポケット線量計による $\gamma$ 線の線量測定值と理研製 $\boldsymbol{\gamma}$ 線用ポケット線量計の $\boldsymbol{\gamma}$ 線の線量測定值は体䅡が一定 でも感度が串うので $\mathrm{Cs}^{137}$ (2.5Ci) の線源で線量校正を 行った。炉内の $\gamma$ 線のエネルギー数 $\mathrm{KeV} \sim$ 数 $\mathrm{MVe}$ ま で分布しているので $0.7 \mathrm{MeV}$ でピークをもつ $\mathrm{Cs}^{137}$ を 代表として利用することが有効である。このとき線量校 正に使用したのはVictoreen 社 Rメータ（測定範囲 0 〜25 R）である。また熱中性子用ポケット線量垶の $\gamma$ 線 による影響をみるためにはこの線量計にカドミウム で被覆して熱中性子束を除くへきであるが，これに代っ

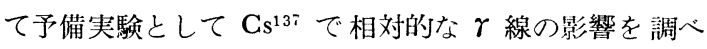
た。

\section{4. 実 験 結 果}

（1）高速中性子線量計の線量校正について

測定場所における中性子の平均エネルギーが $2 \mathrm{MeV}$ で $1 \mathrm{mrem} に$ 相当する粒子束密度の時間積分量は第 1 表 に示すように，科学技術庁報告とS.John 氏との比較 值において前者が後者より $30 \%$ 多くなっている。このそ れぞれの值を使った高速中性子の線量校正值は，第 2 表 第 1 図に示す。

（2）熱中性子線量計の線量校正について

測定場所における熱中性子の平均エネルギーが 0.025 $\mathrm{eV}$ で $1 \mathrm{mrem} に$ 相当する粒子束密度の時間積分量は, 第 1 表に示すように科学技術庁報告と S. John 氏及び Los Alamos Socientific Labrotory 報告との比較值がほ とんど一致したよい值を示している。それぞれの值を使 った熱中性子の線量校正值は第 3 表, 第 2 四に示す。 
第 1 表

\begin{tabular}{|c|c|c|c|c|c|c|}
\hline $\begin{array}{l}\text { 中 性 子 } \\
\text { エネルギー } \\
\text { ( } \mathrm{MeV})\end{array}$ & $\begin{array}{r}\text { 1) } \\
Q F\end{array}$ & $\begin{array}{l}\text { 100mrem } \\
\mathrm{n} / \mathrm{cm}^{2} \mathrm{sec}\end{array}$ & $\begin{array}{l}300 \mathrm{mrem}^{3)} \\
\mathrm{n} / \mathrm{cm}^{2} \mathrm{sec}\end{array}$ & $\begin{array}{l}\text { ミリレムに相当 } \\
\text { する粒子束密度 } \\
\text { の時間積分量 }\end{array}$ & $\begin{array}{l}1 \text { ミリレムに相 } \\
\text { 当する粓子束密 } \\
\text { 度の時間積分量 }\end{array}$ & $\begin{array}{l}\text { (科学技術打)4) } \\
1 ミ \text { ミ公に相 } \\
\text { 当する粒子束密 } \\
\text { 度の時間積分量 }\end{array}$ \\
\hline Thermal & 3 & 670 & $\begin{array}{l}(2000)^{*} \\
2000\end{array}$ & 964,800 & 955,600 & 960,000 \\
\hline 0.0001 & 2 & 500 & $\begin{array}{l}(1500)^{*} \\
1500\end{array}$ & 720,000 & 720,000 & 480,000 \\
\hline 0.005 & 2.5 & 570 & $\begin{array}{c}(1750)^{*} \\
1700\end{array}$ & 835,200 & 817,200 & $C$ \\
\hline 0.02 & 5 & 280 & 850 & 40,320 & 40,680 & ( \\
\hline 0.1 & 8 & 80 & 250 & 115,200 & 11,988 & 96,000 \\
\hline 0.5 & 10 & 30 & 90 & 40,200 & 47,880 & 38,400 \\
\hline 1.0 & 10.5 & 18 & 55 & 25,920 & 26,388 & 28,800 \\
\hline $\begin{array}{c}(2.0) \\
2.5\end{array}$ & $\begin{array}{l}(8.8) \\
8\end{array}$ & $\begin{array}{c}(19) \\
20\end{array}$ & $\begin{array}{c}(58) \\
60\end{array}$ & $\begin{array}{c}(27,360) \\
28,800\end{array}$ & $\begin{array}{c}(27,828) \\
28,800 \\
\end{array}$ & $\begin{array}{c}(19,200) \\
16,800\end{array}$ \\
\hline 5.0 & 7 & 18 & $\begin{array}{l}(50)^{*} \\
55\end{array}$ & 25,920 & 26,498 & 14,400 \\
\hline 7.5 & 7 & 17 & 50 & 24,780 & 24,012 & 14,400 \\
\hline 10.0 & 6.5 & 17 & 50 & 24,780 & 24,012 & 14,400 \\
\hline $10 \sim 30$ & & $10^{*}$ & $30 *$ & 41,400 & 14,400 & 14,400 \\
\hline
\end{tabular}

( ) 推定值

( )* D. E. Hankins; A Neutron Monitoring Instrument Having a Response Approximately Proportional to the Dose Rate from Thermal to $7.0 \mathrm{MeV}$, LA-2717, August 20, 1962

1), 2), 3), S. John; Health Physics Instrumentation, 83 (1959)

4) 放射線同位元素等による放射線障害の防止に関する法令集 (1960) 告示 (22号) 別表第 5

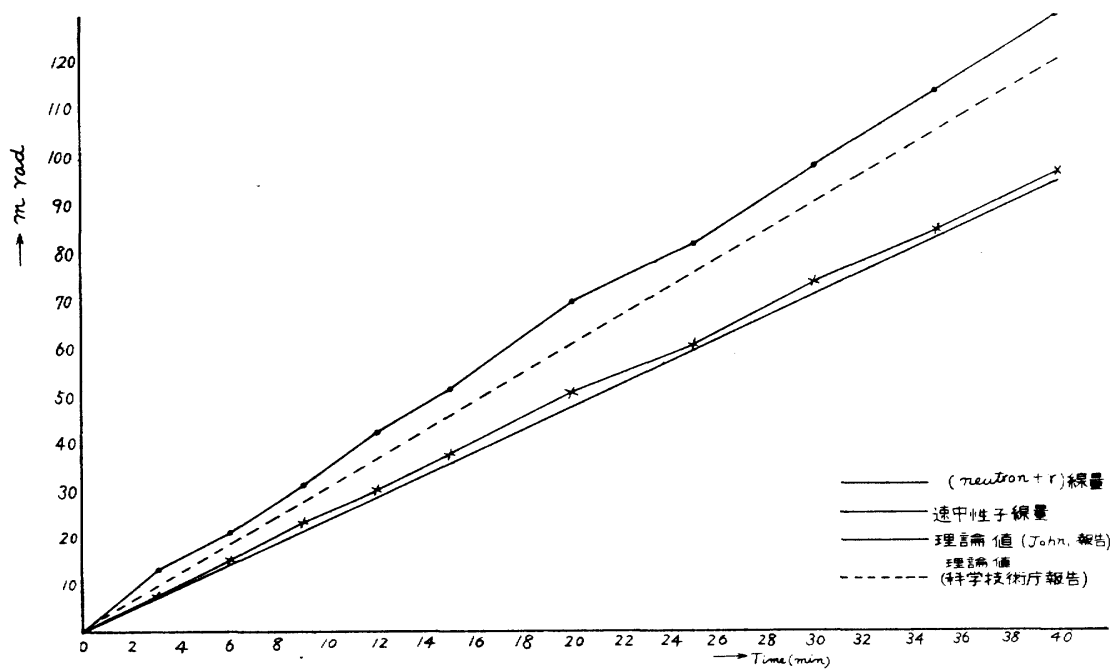

第 1 図 UTR-B 近大原子炉熱出力 $0.01 \mathrm{~W}$ fast neutron flux 約 $1 \times 10^{4} / \mathrm{cm}^{2} \bullet \mathrm{sec}$ (中性子源搟入口) におけ る速中性子線量 
第 2 表 UTR-B 近大原子师熱出力 $0.01 \mathrm{~W}$ neutron flux 約 $1 \times 10^{4} / \mathrm{cm} \cdot \mathrm{sec}$ (中性子源挿入口) における速 性中子線量測定

\begin{tabular}{|c|c|c|c|c|c|c|c|c|c|c|c|c|}
\hline \multirow{3}{*}{ No. 0240} & time $(\min )$ & 0 & 3 & 6 & 9 & 12 & 15 & 20 & 25 & 30 & 35 & 40 \\
\hline & $\begin{array}{c}\text { 線量(mrad) } \\
\gamma+\text { +neutron }\end{array}$ & 13 & 26 & 34 & 44 & 55 & 64 & 82 & 96 & 111 & 126 & 142 \\
\hline & $\begin{array}{r}\text { 線量(mrad) } \\
\text { neutron }\end{array}$ & 0 & 7 & 15 & 23 & 30 & 37 & 50 & 60 & 73 & 84 & 96 \\
\hline
\end{tabular}

第 3 表 UTR-B 近大原子炉熱出力 $0.01 \mathrm{~W}$ thermal neutron flux 約 $1 \times 10^{5} / \mathrm{cm}^{2} \cdot \mathrm{sec}$ (中性子源雨入口) におけ爇中性子線量測定

\begin{tabular}{|c|c|c|c|c|c|c|c|c|}
\hline \multirow{2}{*}{ No. } & \multirow{2}{*}{60075} & $\operatorname{time}(\min )$ & 0 & 3 & 6 & 9 & 12 & 15 \\
\hline & & 線量(mrem) & 18 & 46 & 68 & 89 & 111 & 132 \\
\hline \multirow{2}{*}{ No. } & \multirow{2}{*}{60076} & time $(\min )$ & 0 & 3 & 6 & 9 & 12 & 15 \\
\hline & & 線量(mrem) & 8 & 31 & 53 & 74 & 95 & 118 \\
\hline \multirow{2}{*}{ No. } & \multirow{2}{*}{60077} & time $(\min )$ & 0 & 3 & 6 & 9 & 12 & 15 \\
\hline & & 線量(mrem) & 23 & 45 & 67 & 85 & 107 & 127 \\
\hline
\end{tabular}

第 4 表

\begin{tabular}{|c|c|c|c|c|c|}
\hline & $\begin{array}{l}\text { 線源からの距離 } \\
50 \mathrm{~cm} \\
\text { 照射時間 } 5 \text { 分 }\end{array}$ & $\begin{array}{l}\text { 線源からの距離 } \\
75 \mathrm{~cm} \\
\quad \prime \prime 6 \text { 分 }\end{array}$ & $\begin{array}{l}\text { 線源からの距離 } \\
\begin{array}{l}100 \mathrm{~cm} \\
\quad 10 \text { 分 }\end{array}\end{array}$ & $\begin{array}{l}\text { 線源からの距離 } \\
\begin{array}{l}150 \mathrm{~cm} \\
\prime \prime\end{array} \text { 分 }\end{array}$ & $\begin{array}{l}\text { 線源からの距離 } \\
200 \mathrm{~cm} \\
\quad 11 \quad 20 \text { 分 }\end{array}$ \\
\hline R. meter & $\begin{array}{c}2880 \mathrm{mR} / \mathrm{hr} \\
\prime \prime \prime \prime\end{array}$ & $\begin{array}{c}1250 \mathrm{mR} / \mathrm{hr} \\
/ /\end{array}$ & $720 \mathrm{mR} / \mathrm{hr}$ & $250 \mathrm{mR} / \mathrm{hr}$ & $\begin{array}{l}150 \mathrm{mR} / \mathrm{hr} \\
150 " /\end{array}$ \\
\hline $\begin{array}{l}\text { Bendix 社製 } \\
\text { Fast Neutron } \\
\text { Dosimeter }\end{array}$ & $\begin{array}{l}\left\{\begin{array}{l}2088 \mathrm{mrad} \\
2245 \mathrm{mr} / \mathrm{hr}\end{array}\right. \\
\left\{\begin{array}{l}2076 \mathrm{mrad} \\
2242 \mathrm{mr} / \mathrm{hr}\end{array}\right.\end{array}$ & $\begin{array}{l}870 \mathrm{mrad} \\
936 \mathrm{mR} / \mathrm{hr}\end{array}$ & $\begin{array}{l}528 \mathrm{mrad} \\
570 \mathrm{mR} / \mathrm{hr}\end{array}$ & $\begin{array}{l}250 \mathrm{mrad} \\
270 \mathrm{mR} / \mathrm{hr}\end{array}$ & $\begin{array}{l}141 \mathrm{mrad} \\
152 \mathrm{mR} / \mathrm{hr}\end{array}$ \\
\hline $\begin{array}{l}\text { Kelket 社製 } \\
\text { Model k113 } \\
\text { No. } 2346\end{array}$ & & $\begin{array}{c}1230 \mathrm{mR} / \mathrm{hr} \\
\prime \prime\end{array}$ & $738 \mathrm{mR} / \mathrm{hr}$ & $370 \mathrm{mR} / \mathrm{hr}$ & $210 \mathrm{mR} / \mathrm{hr}$ \\
\hline $\begin{array}{l}\text { Kelket 社製 } \\
\text { Model k113 } \\
\text { No. } 2102\end{array}$ & & $\begin{array}{c}1440 \mathrm{mR} / \mathrm{hr} \\
\prime \prime\end{array}$ & $828 \mathrm{mR} / \mathrm{hr}$ & $380 \mathrm{mR} / \mathrm{hr}$ & $219 \mathrm{mR} / \mathrm{hr}$ \\
\hline $\begin{array}{l}\text { Bendix 社製 } \\
\text { thermal 角 } \\
\text { No. } 60075\end{array}$ & $\begin{array}{l}36 \mathrm{mr} / \mathrm{hr} \\
24 \quad \prime\end{array}$ & & & & \\
\hline $\begin{array}{l}\text { Bendix 社製 } \\
\text { thermal 用 } \\
\text { No. } 60076\end{array}$ & $\begin{array}{c}36 \mathrm{mrem} \\
45 \mathrm{mr} / \mathrm{hr} \\
24 \mathrm{mrem} \\
3 \mathrm{mr} / \mathrm{hr}\end{array}$ & $\begin{array}{l}10 \mathrm{mrem} \\
1.3 \mathrm{mR} / \mathrm{hr}\end{array}$ & $\begin{array}{l}12 \mathrm{mrem} \\
15 \mathrm{mR} / \mathrm{hr}\end{array}$ & $\begin{array}{l}10 \mathrm{mrem} \\
1.3 \mathrm{mR} / \mathrm{hr}\end{array}$ & $\begin{array}{l}6 \mathrm{mrem} \\
0.7 \mathrm{mR} / \mathrm{hr} \\
9 \mathrm{mrem} \\
11 \mathrm{mR} / \mathrm{hr}\end{array}$ \\
\hline $\begin{array}{l}\text { Bendix 社製 } \\
\text { thermal 用 } \\
\text { No. } 60077\end{array}$ & $\begin{array}{l}60 \mathrm{mrem} \\
75 \mathrm{mR} / \mathrm{hr}\end{array}$ & $\begin{array}{l}10 \mathrm{mrem} \\
13 \mathrm{mR} / \mathrm{hr}\end{array}$ & $\begin{array}{l}12 \mathrm{mrem} \\
15 \mathrm{mR} / \mathrm{hr}\end{array}$ & $\begin{array}{l}10 \mathrm{mrem} \\
12 \mathrm{mR} / \mathrm{hr}\end{array}$ & $\begin{array}{l}3 \mathrm{mrem} \\
0.4 \mathrm{mR} / \mathrm{hr} \\
9 \mathrm{mrem} \\
11 \mathrm{mR} / \mathrm{hr}\end{array}$ \\
\hline $\begin{array}{l}\text { Bendix 社製 } \\
\gamma \text { 線 用 } \\
\text { No. } 60077\end{array}$ & $\begin{array}{l}60 \mathrm{mR} / \mathrm{hr} \\
24 \prime \prime\end{array}$ & $10 \mathrm{mR} / \mathrm{hr}$ & $12 \mathrm{mR} / \mathrm{hr}$ & $10 \mathrm{mR} / \mathrm{hr}$ & $\begin{array}{c}15 \mathrm{mR} / \mathrm{hr} \\
3 \mathrm{mR} / \mathrm{hr}\end{array}$ \\
\hline 理研製 No. 7344 & & $1590 \quad \prime \prime$ & & $480 \quad \prime \prime$ & \\
\hline
\end{tabular}




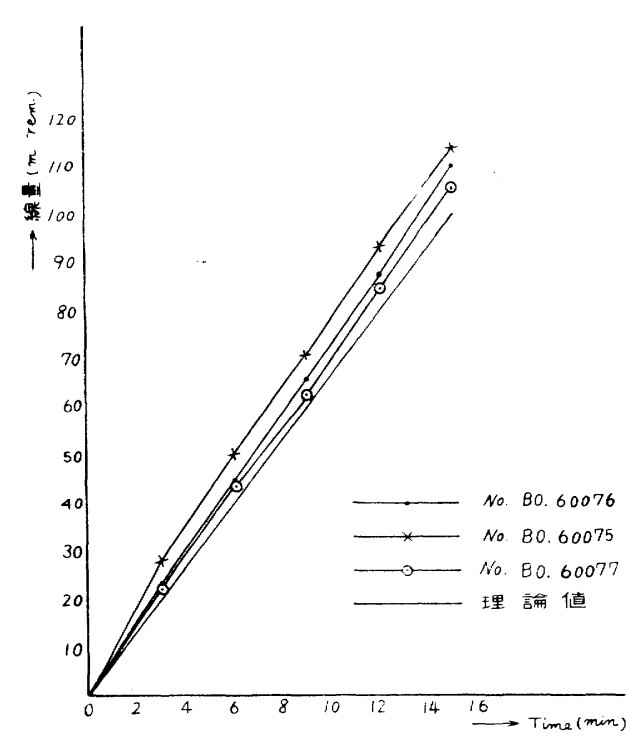

第 2 図 UTR-B 近大原子炉熱出力 $0.01 \mathrm{~W}$ thermal neutron flux 約 $1 \times 10^{5} / \mathrm{cm}^{2} \cdot \mathrm{sec}$ (中性子源挿入口) における熱中性子線量

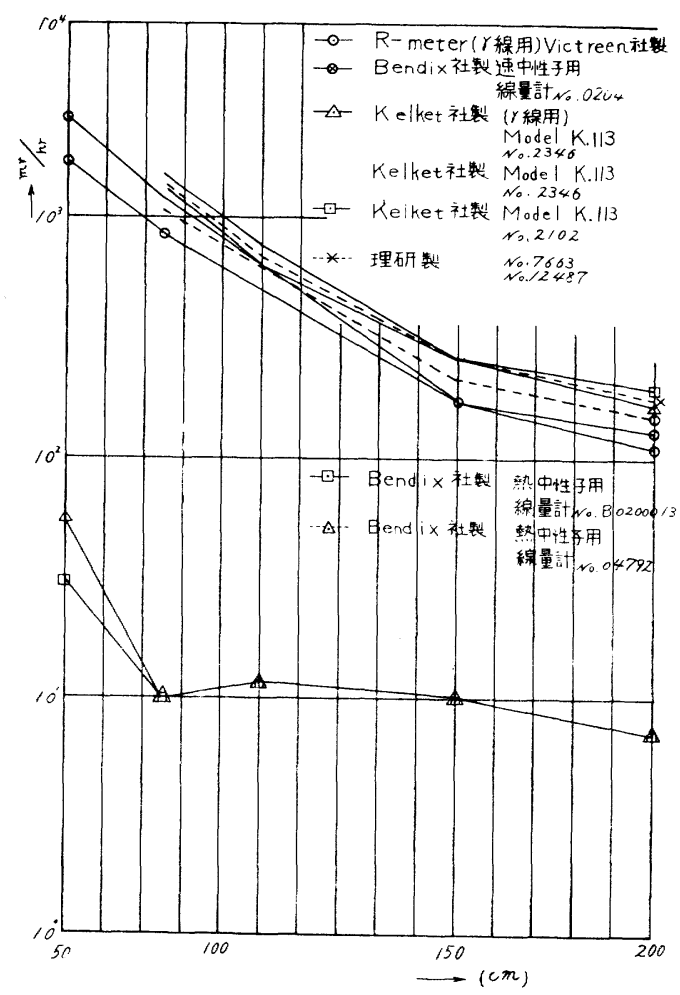

第 3 困 中性子線量計に対する $\gamma$ 線つ感度

\section{(3) $\gamma$ 線の影響について}

高速中性子用ホケット線量尌と熱中性子用ボケット線 量計及び $\gamma$ 線用ホケット線量計の

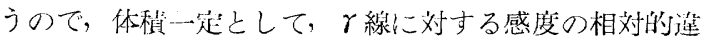
いを $\operatorname{Cs}^{137}(2.5 \mathrm{c})$ で䰜へた。この場合 $\gamma$ 線の方间の均一 性がわるいので䦌題が残るが，兴の結果は第 4 表, 第 3 図に示す。

\section{5. 考察}

（1）この高速中性子用緗量部 (neutron $+\gamma$ 用) は例元 ば核爆発のように瞬閣的にn・ $\gamma$ 其に極めて大きな強 度で放出されるような場合に対しては，なお難しい問 题が多く残って㧍り，その点については今後検討を進 めなければならない。

（2）第 1 表からわかるように $1 \mathrm{mrem} に$ に相当する粒子 束密度の時間積分量が報告によって進うので，その 相刘的器差 $20 \%$ 以内で科学技術厅報告, S. John 氏報 告，また資料㤝分でないが Los Alamos Scientific Laboratory 報告と一致することがわかった。熱中性 子用中性子線量計の $\gamma$ 線の影響については Cs ${ }^{137}$ を用 いて行なったので， $、$ 線が方问的には均一でないが， 実䲗贵差内でその晾響のないことがわかった。

対象となる速中性子ないし 分布存考えて取り扱い，検鲀解析をしなければならな いが，今回はとりあえずそれぞれ代表値をもって表現

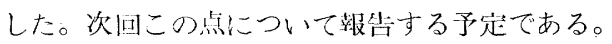

本佃究において御協力頂いた明星大学物理学科主任教 授鈴木辰三郎博士（前陸上自衛隊化学学校長），理版作

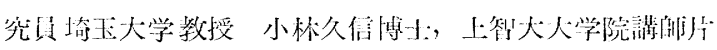
蔺治雄氏に感謝致します。

\section{参考文献}

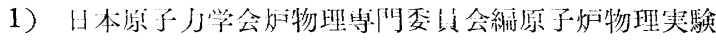
(1964)

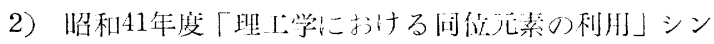
ホジューム

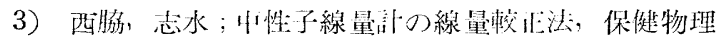
協義会俳究登食 (1965) 紧旨集

4) G. N. Whyte; Principle of Radiation Dosimetry, Academic Press, (1959)

5) D. E. Hankins; LA-2717 (1962)

6) H O. Wyckoff and F.H. Attix; N. B.S-HandBook P. 63 (1959)

7) S.John; Health Physics Instrumentation, 83 (1959) 
8）科学技術庁：放射性同位元素等による放射線障害の 防止に関する法令集 182 (1960)

9) 日本電気学会 : 原子力計測器の現状と問題点 (1965)

10) 森 内 和之：応用物理学会誌 Vol. 35, 84 (1966)

11) J.A. Dennis ; 原子力学会誌 Vol. 8, 36 (1966)

12) William J. Price; Nuclear Radiation Detection, (1958)

13) Lea, D. E ; Action of Radiation on Living Cells (1947)

14) R. L. Bramblett, R. I. Ewing and T.W. Bonner, Nucl. Instr. Method 9, 1 (1960)

15) E. B. Wagner and G. S. Hurst, Rev. Sci. Inst. 29, 153 (1958)

16) H. O. Wyckoff and F. H. Attix, Design of Free-air
Ionization Chamber, National Bureau of Stands

Handbook 64, (1957)

17) 横田, 中島, 上杉: Radioisotopes 10, 387 (1961)

18) 中村, 志水: 日本原子力学会誌 Vol. 6, No. 3, PP. 129 134 (1964)

19) 中村, 志水: 近畿大学原子力研究所年報 Vol. 1, P. 57, 近畿大学原子力研究所

20) 中村, 志水: 近畿大学原子力研究所年報 Vol. 2, P. 7, 近畿大学原子力研究所

21）西脇, 本田：近畿大学原子力研究所年報 Vol. 2, P. 51 近畿大学原子力研究所

（1966年12月 2 日受理） 